\title{
REAKSI PASAR MODAL INDONESIA TERHADAP PEMILIHAN UMUM PRESIDEN DAN WAKIL PRESIDEN 17 APRIL 2019 (EVENT STUDY PADA ABNORMAL RETURN SAHAM LQ45 DI BURSA EFEK INDONESIA)
}

\author{
Felia Sunarga \\ Program Studi Magister Manajemen Universitas Tarumanagara \\ fsunarga@gmail.com
}

Masuk : 06-12-2019, revisi : 07-01-2020 diterima untuk diterbitkan : 07-01-2020

\begin{abstract}
Economic and socio-political event that contained information would cause investor to think and consider the rate of risk and return from their investment. This research is aimed to find whether the capital market react to the Indonesian Presidential Election 17 April 2019. Results from this research is expected to aid investors in their decision-making for future investment. Approach used in this research is event study, with observations done to abnormal return 7 days before and 7 days after the event. Secondary data is used, including a list of companies included in LQ45 from August 2018-January 2019 and February 2019-July 2019, daily closing price during the observation period, LQ45 index and Trading Volume Activity (TVA) of LQ45. Model used in estimating expected return is market-adjusted model. Sample is taken using purposive sampling, with total of 41 companies. Analysis is done using Wilcoxon signed-ranked test with rate of significance 5\%. Results showed there is no difference in abnormal return before and after Presidential Election 17 April 2019. This means that contained information does not affect investors in the capital market.
\end{abstract}

Keywords : Abnormal Return, Event Study, Presidential Election

Abstrak : Peristiwa ekonomi dan sosial-politik yang terjadi dalam negeri yang memiliki kandungan informasi akan membuat investor memikirkan serta memperhitungkan kembali tingkat resiko dan return dana yang telah mereka tanamkan di pasar modal. Penelitian ini bertujuan untuk menemukan ada tidaknya reaksi pasar modal Indonesia terhadap peristiwa Pemilu Presiden 17 April 2019. Hasil penelitian ini di harapkan dapat membantu investor dalam pengambilan keputusan berinvestasi atau menanamkan modal. Pendekatan yang digunakan dalam penelitian adalah event study dengan melakukan pengamatan terhadap abnormal return selama 7 hari sebelum peristiwa dan 7 hari sesudah peristiwa. Data dalam penelitian ini merupakan data sekunder, meliputi daftar perusahaan yang termasuk ke dalam LQ45 periode Agustus 2018 - Januari 2019 dan Februari 2019 - Juli 2019, daftar closing price harian selama periode pengamatan, indeks LQ45 dan Trading Volume Activity (TVA) perusahaan LQ45. Model yang digunakan dalam estimasi expected return adalah market adjusted model. Untuk teknik pengambilan sampel digunakan metode purposive sampling, dengan total sampel 41 perusahaan. Analisa data menggunakan metode Wilcoxon signed rank test dengan tingkat signifikansi 5\%. Hasil penelitian menunjukkan tidak adanya perbedaan abnormal return perusahaan LQ45 sebelum dan sesudah Pemilu 17 April 2019. Ini berarti informasi yang ada tidak memiliki kandungan informasi untuk dapat mempengaruhi investor pasar modal.

Kata Kunci : Abnormal Return, Event Study, Pemilihan Umum

\section{LATAR BELAKANG}

Peristiwa politik suatu negara merupakan suatu hal yang sangat menarik untuk diteliti dan diamati. Ini disebabkan oleh dampak peristiwa tersebut yang mempunyai hubungan dengan berbagai aspek sosial, ekonomi, keamanan serta aspek-aspek lainnya. Peristiwa politik yang 
terjadi di suatu negara tidak dapat di abaikan dan di pandang sebelah mata, dikarenakan oleh risiko positif maupun negatif yang dapat terjadi pada kelangsungan usaha yang dijalankan.

Pasar modal (capital market) tidak pernah lepas keterkaitannya dengan kehidupan ekonomi suatu negara dan memiliki peran strategis sebagai salah satu sumber pembiayaan dunia usaha serta dalam menunjang pelaksanaan pembangunan nasional. Sebagai salah satu instrumen ekonomi, pasar modal juga sangat dipengaruhi oleh berbagai peristiwa yang memiliki kandungan informasi untuk para investor.

Pentingnya pasar modal dalam perekonomian negara mempengaruhi seberapa sensitif pasar modal tersebut terhadap peristiwa-peristiwa yang terjadi di sekitarnya. Karena hal inilah informasi menjadi kebutuhan utama investor pasar modal dalam menanamkan investasi. Dengan adanya informasi yang relevan, investor dapat melakukan penilaian terhadap kinerja emiten sehingga mereka memiliki gambaran expected return yang akan didapat serta risiko atas modal yang mereka akan maupun telah investasikan. Informasi yang diperlukan berasal dari dua sumber, yaitu internal dan eksternal. Ketika pasar bereaksi cepat terhadap segala informasi yang relevan maka pasar dapat disebut pasar modal yang efisien, dan hal tersebut terlihat pada perubahan harga saham melebihi kondisi normal, yang disebut abnormal return.

Peristiwa-peristiwa yang terjadi dalam lingkungan emiten mempengaruhi harga saham yang dapat mengakibatkan terjadinya abnormal return. Selain dari peristiwa yang terjadi dalam lingkungan perusahaan, peristiwa makro seperti kurs valuta asing, regulasi \& deregulasi ekonomi pemerintah, dan perubahan suku bunga tabungan $\&$ deposito juga turut berpengaruh pada fluktuasi harga dan volume perdagangan pasar modal efisien (Manullang, 2004 dan Suryawijaya \& Setiawan, 1998).

Frekuensi harga saham di pasar modal dipengaruhi oleh tingkat permintaan dan penawaran terhadap harga saham tersebut. Berita yang ada di pasar modal, misalnya keadaan keuangan suatu perusahaan akan mempengaruhi harga saham yang di tawarkan kepada masyarakat. Jenis informasi yang beredar juga dapat mempengaruhi profitabilitas suatu perusahaan di masa depan. Sebagai instrumen ekonomi, pasar modal juga tidak dapat dilepaskan dari berbagai macam pengaruh lingkungan, terutama lingkungan ekonomi dan politik. Kondisi makro ekonomi, yang mencakup pertumbuhan ekonomi, tingkat inflasi, nilai tukar mata uang serta kebijakan sektor finansial akan berpengaruh terhadap pertumbuhan pasar modal di Indonesia. Demikian halnya dengan kondisi lingkungan politik, seperti adanya peperangan, kerusuhan politik, pergantian pemerintahan atau peristiwa lain yang berkaitan erat dengan kestabilan perekonomian suatu negara akan berpengaruh pada pertumbuhan pasar modal.

Peristiwa ekonomi dan sosial-politik yang terjadi dalam negeri yang memiliki kandungan informasi akan membuat investor memikirkan serta memperhitungkan kembali tingkat resiko dan return dana yang telah mereka tanamkan di pasar modal. Beberapa event study menunjukan adanya pengaruh peristiwa-peristiwa ekonomi ataupun social-politik terhadap harga dan volume perdagangan saham di pasar modal. Penelitian-penelitian terdahulu yang sudah di lakukan meninjau secara umum reaksi pasar modal terhadap peristiwa-peristiwa politik yang terjadi, dan tidak memfokuskan pada suatu event tertentu. Pemilihan Umum (Pemilu) Presiden merupakan peristiwa penting yang akan menentukan kepemimpinan suatu negara ke depannya, kebijakan-kebijakan yang akan di ambil akan sangat menentukan perekonomian suatu negara. Dengan demikian, sebagai pengembangan dari penelitianpenelitian yang telah terdahulu dilakukan, dirasakan perlu untuk dilakukan penelitian untuk menguji reaksi pasar modal Indonesia terhadap peristiwa sosial-politik dalam negeri.

Pergerakan harga saham di pasar modal bukan hanya dipengaruhi oleh peristiwaperistiwa serta kebijakan ekonomi suatu negara. Kejadian-kejadian non-ekonomi turut berperan dalam memberikan pengaruh terhadap pergerakan harga perusahaan-perusahaan di pasar modal. Suatu peristiwa yang terjadi, yang dapat mempengaruhi harga saham-saham yang diperdagangkan di pasar modal, maka peristiwa tersebut dianggap memiliki kandungan 
informasi bagi para investor dan informasi tersebut juga diterima dengan baik oleh para investor.

Berbagai macam peristiwa ekonomi maupun non-ekonomi yang terjadi di dalam negeri dapat mempengaruhi besar-kecilnya peluang perusahaan emiten dalam menghasilkan untung, sehingga membuat investor memperhitungkan kembali harga saham yang mereka perjualbelikan berdasarkan return yang mereka harapkan serta risiko yang juga mereka tanggung. Peristiwa-peristiwa non-ekonomi, seperti pemilihan Presiden, juga memberikan suatu efek atau dampak tersendiri terhadap stabilitas politik juga keamanan yang akan mempengaruhi kinerja emiten. Hal ini disebabkan jika pemerintah atau pemegang kekuasaan berganti, maka ada kemungkinan hukum ataupun kebijakan-kebijakan yang tadinya berlaku di negara tersebut pun juga diganti.

Berdasarkan pemikiran di atas, hipotesis yang akan diuji pada penelitian ini adalah sebagai berikut:

Ha1: Adanya reaksi pasar secara signifikan atas peristiwa Pemilu 17 April 2019.

$\mathrm{Ha} 2$ : Terdapat perbedaan rata-rata antara abnormal return perusahaan yang terdaftar dalam LQ45 di BEI yang diperoleh investor sebelum dan sesudah berlangsungnya peristiwa Pemilu 17 April 2019.

Ha3 : Adanya perbedaan rata-rata Trading Volume Activity (TVA) secara signifikan sebelum dan sesudah berlangsungnya peristiwa Pemilu.

\section{TINJAUAN PUSTAKA}

Abnormal return adalah return yang tidak sesuai harapan investor. Return tidak normal ini merupakan selisih dari return yang diharapkan dengan return yang benar-benar didapat investor. Terjadinya abnormal return ini bisa disebabkan oleh kejadian-kejadian tertentu, seperti misalnya penawaran perdana sahaam, hari libur nasional atau suasana politik yang tidak menentu.

Event study adalah suatu pengamatan atas pergerakan harga saham di pasar modal untuk mengetahui ada tidaknya abnormal return yang diperoleh pemegang saham sebagai akibat dari suatu peristiwa tertentu.

Pemilihan umum merupakan pemilihan yang dilakukan untuk memilih seseorang untuk mengisi jabatan politik tertentu.

\section{METODE}

Penelitian ini menggunakan metode event study, yang mempelajari reaksi pasar terhadap suatu event yang informasinya dipublikasikan sebagai suatu pengumuman (Yogianto, 2000) serta bertujuan untuk mengukur hubungan antara suatu peristiwa dengan tingkat return di pasar modal. Studi peristiwa merupakan suatu pengamatan mengenai harga saham di pasar modal untuk mengetahui apakah ada abnormal return yang diperoleh pemegang saham sebagai akibat dari suatu peristiwa tertentu (Peterson, 1998). Menurut Kritzman, studi peristiwa memiliki tujuan untuk mengukur hubungan antara suatu peristiwa yang mempengaruhi surat berharga dan pendapatan (return) dari surat berharga tersebut (1994, dalam Lamaisigi 2002). Selain itu, menurut Mackinlay, event study juga dapat digunakan sebagai alat pengukur dampak suatu peristiwa ekonomi terhadap nilai perusahaan (1997, dalam Meidawati \& Harimawan 2018).

Dalam penelitian ini, peristiwa yang dipilih adalah Pemilihan Umum (Pemilu) Presiden 17 April 2019. Variabel yang diteliti adalah volume perdagangan saham dan tingkat keuntungan tidak normal (abnormal return) di Bursa Efek Indonesia (BEI). Event window yang digunakan adalah 7 hari sebelum dan 7 hari setelah. Harga saham yang dipakai adalah harga penutupan (closing price), harga saat akhir bursa. Pengambilan sampel menggunakan teknik purposive sampling. 
PEMBAHASAN DAN HASIL

Tabel 1

Statistik Deskriptif Abnormal Return Saham Periode Pengamatan

\begin{tabular}{|l|c|c|}
\hline & Mean & Std. Deviation \\
\hline SEBELUM PEMILU & .0014959374 & .0178819016 \\
SESUDAH PEMILU & .0022123760 & .0195524775 \\
Valid N (listwise) & & \\
\hline
\end{tabular}

Pada tabel diatas, dapat dilihat nilai rata-rata abnormal return periode sebelum pemilihan sebesar 0.00146. Untuk nilai rata-rata abnormal return setelah pemilihan sebesar 0.00221 .

Tabel 2

Hasil Perhitungan Average Abnormal Return (AAR) Saham LQ45

7 Hari Sebelum dan \& Hari Setelah Pemilu

\begin{tabular}{|c|r|c|r|}
\hline \multicolumn{2}{|c|}{ AAR SEBELUM } & \multicolumn{2}{c|}{ AAR SETELAH } \\
\hline $\mathrm{H}-1$ & 0.004052 & $\mathrm{H}+1$ & 0.0015 \\
\hline $\mathrm{H}-2$ & 0.000819 & $\mathrm{H}+2$ & 0.004364 \\
\hline $\mathrm{H}-3$ & 0.000835 & $\mathrm{H}+3$ & -0.00382 \\
\hline $\mathrm{H}-4$ & -0.00186 & $\mathrm{H}+4$ & 0.002454 \\
\hline $\mathrm{H}-5$ & 0.004503 & $\mathrm{H}+5$ & 0.009929 \\
\hline $\mathrm{H}-6$ & 0.00491 & $\mathrm{H}+6$ & 0.001611 \\
\hline $\mathrm{H}-7$ & -0.00279 & $\mathrm{H}+7$ & -0.00056 \\
\hline
\end{tabular}

Dari hasil yang ditemukan pada tabel, dengan tingkat signifikan pada 5\% (0.05), ditemukan ada dua hari yang secara signifikan menghasilkan abnormal return bagi investor. Pada H-6 dengan nilai 0.031 dan pada $\mathrm{H}+5$ dengan nilai 0.001 . Kedua abnormal return yang terjadi ini bersifat positif.

Tabel 3

Hasil Uji Normalitas Kolmogorov-Smirnov

\begin{tabular}{|c|c|c|c|}
\hline & & $\begin{array}{l}\text { SEBELUM } \\
\text { PEMILU }\end{array}$ & $\begin{array}{l}\text { SESUDAH } \\
\text { PEMILU }\end{array}$ \\
\hline $\bar{N}$ & & 288 & 288 \\
\hline \multirow{2}{*}{ Normal Parameters ${ }^{a, b}$} & Mean & .0014959374 & .0022123760 \\
\hline & Std. Deviation & .0178819016 & .0195524775 \\
\hline \multirow[t]{3}{*}{ Most Extreme Differences } & Absolute & .059 & .092 \\
\hline & Positive & .059 & .092 \\
\hline & Negative & -.041 & -.049 \\
\hline Test Statistic & & .059 & .092 \\
\hline Asymp. Sig. (2-tailed) & & $.017^{\circ}$ & $.000^{\circ}$ \\
\hline
\end{tabular}

Berdasarkan hasil uji normalitas diatas, dapat dilihat nilai abnormal return pada periode penelitian memiliki $\mathrm{p}$ value 0.017 untuk sebelum pemilihan dan 0.000 untuk sesudah pemilihan. Kedua nilai tersebut lebih kecil dari nilai signifikansi yang ditentukan, yaitu 0.05. Ini berarti distribusi data tidak normal. Selanjutnya digunakan uji Wilcoxon untuk analisis data.

Tabel 4

Wilcoxon Signed Rank Test Abnormal Return Saham Sebelum \& Setelah Pemilu

\begin{tabular}{|l|r|}
\hline & $\begin{array}{c}\text { SESUDAH } \\
\text { PEMILU- } \\
\text { SEBELUM } \\
\text { PEMILU }\end{array}$ \\
\hline$Z$ & $-.409^{\mathrm{b}}$ \\
Asymp. Sig. (2-tailed) & .682 \\
\hline
\end{tabular}

Dari hasil pengujian Wilcoxon, didapati tingkat signifikansi hasil pengujian sebesar 0.682 , lebih besar dari nilai signifikansi yang ditentukan yaitu 0.05 (5\%). Maka dapat disimpulkan bahwa hipotesis alternatif ditolak atau tidak terdapat perbedaan abnormal return yang diperoleh investor sebelum dan sesudah Pemilu Presiden dan Wakil Presiden 17 April 2019.

Tabel 5

Uji Beda Average Trading Volume Activity (ATVA)

\begin{tabular}{|c|c|c|c|}
\hline & ATVA Sebelum & & ATVA Sesudah \\
\hline $\mathrm{H}-1$ & 0.255796142 & $\mathrm{H}+1$ & 0.289074305 \\
\hline $\mathrm{H}-2$ & 0.253257221 & $\mathrm{H}+2$ & 0.260125205 \\
\hline $\mathrm{H}-3$ & 0.276532892 & $\mathrm{H}+3$ & 0.205647665 \\
\hline $\mathrm{H}-4$ & 0.258727995 & $\mathrm{H}+4$ & 0.212359203 \\
\hline $\mathrm{H}-5$ & 0.264548878 & $\mathrm{H}+5$ & 0.290347596 \\
\hline $\mathrm{H}-6$ & 0.27510077 & $\mathrm{H}+6$ & 0.236989648 \\
\hline $\mathrm{H}-7$ & 0.447343327 & $\mathrm{H}+7$ & 0.244851959 \\
\hline Average & 0.290186747 & Average & 0.248485083 \\
\hline Signifikansi & \multicolumn{3}{|c|}{ Tidak signifikan } \\
\hline
\end{tabular}


Dari Tabel 5 dapat terlihat bahwa rata-rata trading volume activity sebelum Pemilu, yaitu sebesar 0.29019 lebih tinggi dari rata-rata trading volume activity setelah Pemilu sebesar 0.24829. Hal ini menunjukkan terjadinya penurunan aktivitas perdagangan saham-saham yang termasuk ke dalam LQ45.

\section{Pembahasan}

Hasil penelitian menunjukkan dari sebanyak 41 perusahaan sampel LQ45 yang diteliti tidak menunjukkan adanya perbedaan abnormal return yang didapat investor antara sebelum dan sesudah terjadinya Pemilu 2019.

Hasil pengujian (Tabel 4) terhadap perbedaan rata-rata abnormal return antara sebelum dan sesudah peristiwa Pemilu 2019 dilaksanakan menunjukkan bahwa hipotesis alternatif (Ha) ditolak, atau tidak terdapat perbedaan abnormal return yang diperoleh investor sebelum dan sesudah Pemilu 2019. Hal ini mungkin disebabkan oleh tindakan yang pelaku pasar lebih cenderung memilih untuk mengamati terlebih dahulu keadaan pasar serta melakukan spekulasi yang mereka anggap akan menguntungkan mereka hari-hari seputar pelaksanaan Pemilu 2019.

Terpilihnya kembali Joko Widodo sebagai Presiden Indonesia untuk periode jabatan yang kedua kalinya cukup menimbulkan pro dan kontra dari berbagai pihak dan kalangan. Adanya kemungkinan negara menjadi tidak stabil setelah pengumuman pemenang membuat investor enggan untuk segera menanamkan modal mereka. Hasil quick count dari beberapa lembaga pada waktu itu menyatakan pasangan Joko Widodo - Ma'aruf Amin unggul, juga dianggap belum memastikan hasil akhir dari pemenang Pemilu. Investor memiliki kecenderungan untuk mengambil sikap negatif dan khawatir terhadap peristiwa-peristiwa politik, seperti yang dinyatakan Peterson (1999). Isu-isu yang beredar dalam proses penghitungan quick count hasil Pemilu dapat juga memberikan dampak pada keputusan investor untuk berinvestasi atau tidak. Adanya beberapa kalangan yang mengindikasikan terjadinya kecurangan, baik itu meliputi pemungutan suara di TPS, kecurangan pada kertas pemilihan dan kecurangan administrasi membuat investor memilih untuk 'wait and see' selama beberapa hari setelah pelaksanaan pemilihan demi mendapatkan kepastian untuk berinvestasi.

Alasan lain tidak adanya perbedaan secara signifikan atas average abnormal return sebelum dan sesudah Pemilu 2019 adalah dengan kemenangan yang kembali diperoleh Jokowi, investor berpandangan kebijakan-kebijakan yang akan diterapkan selama lima tahun ke depan tidak akan jauh berbeda dengan yang telah diterapkan lima tahun sebelumnya. Karena hal ini, investor pun tidak bereaksi atas adanya informasi tersebut. Dari hasil uji hipotesis kedua ini, maka dapat disimpulkan bahwa tidak ada perbedaan secara signifikan abnormal return antara sebelum dan sesudah peristiwa Pemilu. Hasil ini konsisten dengan hasil penelitian Trisnawati (2011), Luhur (2010), Wardani (2018) serta Budiman (2015).

Uji beda trading volume activity pada Tabel 11 menunjukkan rata-rata trading volume activity sebelum Pemilu, yaitu sebesar 0.29019. Angka ini lebih tinggi dari rata-rata trading volume activity setelah Pemilu yang hanya sebesar 0.24829. Sedangkan untuk uji t yang dilakukan atas trading volume activity menunjukkan bahwa secara statistik, TVA tidak signifikan. Tingkat signifikansi data adalah 0.159, lebih tinggi dari 0.05. Ini berarti H0 diterima, sedangkan Ha ditolak. Artinya, tidak ada perbedaan rata-rata trading volume activity secara signifikan sebelum dan sesudah peristiwa Pemilu Presiden dan Wakil Presiden 17 April 2019. Dengan tidak adanya perbedaan secara signifikan antara rata-rata TVA sebelum dan sesudah peristiwa mengindikasikan tidak adanya kenaikan kegiatan perdagangan secara besarbesaran.

\section{KESIMPULAN}

Berdasarkan hasil penelitian dan pengamatan yang dilakukan terhadap 41 perusahaan LQ45 yang termasuk ke dalam populasi sampel selama 15 hari bursa, dapat ditarik kesimpulan bahwa pasar bereaksi pada dua hari bursa yang termasuk event period, yaitu H-6 dan H+5 
dimana pada kedua hari tersebut, abnormal return positif dihasilkan.Tidak ada perbedaan ratarata secara signifikan untuk abnormal return perusahaan yang terdaftar dalam LQ45 di BEI baik sebelum maupun sesudah Pemilu Presiden dan Wakil Presiden 17 April 2019.

Tidak adanya perbedaan signifikan untuk rata-rata trading volume activity (TVA) saham LQ45 yang termasuk dalam BEI sebelum dan sesudah berlangsungnya peristiwa Pemilu Presiden dan Wakil Presiden 17 April 2019.

\section{SARAN}

Untuk pengembangan penelitian-penelitian selanjutnya, berikut adalah beberapa saran yang diajukan:

1. Pemegang saham dan investor

Dengan memanfaatkan informasi yang ada, investor akan lebih diuntungkan. Para investor diharapkan dapat menggunakan dan memanfaatkan informasi yang ada dalam melakukan aktivitas perdagangan.

2. Penelitian selanjutnya

Menambah jumlah sampel penelitian dan tidak membatasi hanya dengan menggunakan perusahaan LQ45. Melakukan penelitian pada sektor-sektor tertentu, menambah rentang jumlah hari pengamatan, menggunakan model lain seperti market model atau meanadjusted model. Selain itu, untuk penelitian selanjutnya, variabel lain dapat ditambahkan, seperti risiko suku bunga, risiko inflasi, risiko bisnis, risiko likuiditas atau risiko nilai tukar mata uang.

\section{DAFTAR PUSTAKA}

Budiman, A. (2015). Analisis Perbandingan Average Return dan Average Trading Volume Activity Sebelum dan Sesudah Peristiwa Pemilihan Umum Presiden dan Wakil Presiden Tahun 2009 dan 2014 (Study Pada Saham-Saham LQ45 di Bursa Efek Indonesia). Skripsi. Universitas Negeri Semarang. Semarang.

Lamaisigi, Treisye Ariance. (2002). Reaksi Pasar Modal Terhadap Peristiwa Pergantian Presiden Republik Indonesia 23 Juli 2001: Kajian Terhadap Return Saham LQ45 di PT Bursa Efek Jakarta. Proceeding Symposium Nasional Akuntansi V. 272-285.

Luhur, S. (2010). Reaksi Pasar Modal Indonesia Seputar Pemilihan Umum 8 Juli 2009 pada Saham LQ45. Jurnal Keuangan dan Perbankan. 14 (2). 249-262. Yogyakarta: UPN Veteran Yogyakarta.

Manullang, T. Laurence Adolf. (2004). Analisis Efisiensi Pasar Modal Indonesia Menggunakan Pendekatan Multiple Event Sosial dan Politik dan Ekonomi. Disertasi. Universitas Persada Indonesia YAI. Jakarta.

Peterson, P. (1999). Event Study: A Review of Issues and Methodology. Quarterly Journal of Business and Economics. 28 (3). Summer.

Suryawijaya, M. A. dan Setiawan, F. A. (1998). Reaksi Pasar Modal Indonesia Terhadap Peristiwa Politik Dalam Negeri, Event Study pada Peristiwa 27 Juli 1996. Kelola. 18 (7). 137-153.

Trisnawati, F. (2011). Pengaruh Peristiwa Politik terhadap Perubahan Volume Perdagangan Saham dan Harga Saham. Pekbis Journal. 3. 528-535. Bandung: Universitas Padjajaran.

Wardani, Laksmi Swastika. (2012). Reaksi Pasar Modal Indonesia Terhadap Peristiwa

Pemilihan Gubernur DKI Jakarta Putaran II 2012. (Event Study pada Saham Anggota Indeks Kompas 100) 